\title{
Measuring Environmental Performance of BANKS: EVIDENCE FROM CARBON DISCLOSURE PROJeCT (CDP) REPORTING BANKS
}

\author{
Alfred Bimha* \\ University of South Africa
}

Received: September 2015

\author{
Godwell Nhamo" \\ University of South Africa
}

Accepted: October 2016

\begin{abstract}
The need to measure the environmental performance of banks stems from the important role they occupy in the financial system as intermediator between savers and borrowers. Moreover, the growth in environmentally friendly business has created a need for banks to reconsider their business models. Potential investors are now looking for companies with green operations credentials. This study embarked on measuring and investigating banks, by country of origin, that are performing well in implementing their own environmental policies. Using the Carbon Disclosure Project (CDP) questionnaire answers, the study constructed an Environmental Management Performance (EMP) scoring index that was compared to the banks' Environmental Operational Performance (EOP) indicators. Data for the period 2011 to 2014 was collected from 68 banks from 26 countries. The results aggregated on average performance score for the EMP and average result for the EOP. Finally, the EMP average scores were correlated with EOP averaged results. The main discovery of the study was a significant negative correlation between EMP and EOP in most banks. However, the overall averaged sample results show that the negative correlation has no significance at all. This means that implementing an environmental policy has no implications, given the improved environmental operational performance of banks between 2011 and 2014. The major outcome from the research is that, in the short term, environmental management policies cannot yield positive improvement in the environmental operational policies for banks.
\end{abstract}

Keywords

Environmental Management Performance, Sustainability, Stakeholders, Carbon Disclosure, Banks

* Mr A Bimha is a Doctorate student in the Department of Finance, Risk Management and Banking at UNISA, Pretoria, South Africa. [alfredbimha@gmail.com]

\#Prof G Nhamo is a professor and Chief Researcher in the Institute for Corporate Citizenship at UNISA, Pretoria, South Africa. [nhamog@unisa.ac.za] 


\section{INTRODUCTION}

It is estimated that banking institutions' financing of projects backed by fossil fuels is nine times more than what they are putting into renewable energy projects, and this has raised concern over the role that banks play in ameliorating the impact of climate change (Warmerdam et al., 2015). Among its major findings, the Intergovernmental Panel on Climate Change's (IPCC) $5^{\text {th }}$ Assessment report (IPCC, 2014) indicated that climate change will affect all sectors of the economy and is relevant to investors and financial institutions. Moreover, to reduce the effects of global warming, which leads to climate change and extreme weather events like floods and droughts, there should be a significant decrease in investment in fossil fuel extraction and conventional fossil fuelbased power generation. Such a decrease must be accompanied concurrently by an increase in investments in low-carbon energy and energy efficiency projects. The IPCC further indicates that climate change will affect agriculture and food supply, infrastructure, precipitation and water supply by way of risk that is partially understood, and these are all sectors that banks also finance.

The impact of climate change in different areas is of concern given the intermediary role of banks in the economy. Banks are resource allocators and intermediators between borrowers and investors (Allen and Santamero, 1997). Diamond (1996) postulates the delegated monitoring theory as the notion of investors not having the time and expertise to monitor borrowers for default risk. They therefore engage in indirect financing by using an intermediator (the bank), which monitors debt (loan) contracts issued to it by borrowers that it funds, and issues unmonitored debt (deposit) contracts. The key element in the theory is the costs and benefits of monitoring the loan contract. The rise of environmental risk due to climate change should exacerbate the issues surrounding the delegated monitoring function of banks. In addition, the suppliers of loan funds (investors, depositors) have indicated the need for financial intermediators not using their funds in environmentally risky projects (Lewis and Juravlre, 2010; Sachs and Reid, 2006).

Given the impact of climate change and the opportunities and risks it poses for the financial intermediation role of banks, the environmental performance of banks needs to be measured, in view of their environmental sustainability. This study therefore embarks on unravelling current practices related to measuring bank performance and attempts to craft a bank environmental performance model. The next section briefly focuses on a literature review that explores the theoretical underpinnings of bank performance measurement and corporate environmental performance. This is followed by the materials and methods section, which details the sample, data and proposed model used for this study. Finally, results are presented and discussed before conclusions are drawn, detailing the implications of the research and suggesting future research options.

\section{LITERATURE REVIEW}

\subsection{Corporate Environmental Performance models}

Two prominent articles on Corporate Environment Performance (CEP) are that of Trumpp, Endrikat, Zopf and Guenther (Trumpp et al., 2015), which defines and conceptualises the measures of CEP, and the article by Wan and Tang (2014), a literature review of (EP evaluation. To our best knowledge, the possible earliest work is by Ditz and Ranganathan (1997), where the authors 
indicate four main Environmental Performance Indicators ( $E P I)$ in a business, namely: ( 1 ) materials use, (2) energy consumption, (3) non-product output and (4) pollutant releases. Ditz and Ranganathan contend that the measuring of CEP will assist different stakeholders in a profound way. First, CEP will assist businesses in attracting customers and increasing shareholder value. Second, financial institutions are assisted in that the measuring of CEP will connect CEP to economic value and thus easily embed the EPIs mentioned earlier into investment, insurance and lending decisions. Third, consumers will be able to choose products and/or services based on environmental performance during production, use and disposal phases. Fourth, and on the other hand, communities will be able to benchmark the environmental performance of their local facilities against other facilities around the world. Last, government agencies will use the environmental performance information to evaluate policies and their reforms.

Wan and Tang (2014) indicate that the evolution of CEP has been shaped by international environmental reporting guidelines, provided by the following institutions: (1) WBCSD (World Business Council for Sustainable Development), (2) ISO (International Organisation for Standardisation), (3) UNCTAD (United Nations Conference on Trade and Development) and (4) GRI (Global Reporting Initiative). The WBCSD made the world's first set of eco-efficiency indicators, which are eco-efficiency assessment standards that are used to measure CहP. The formula of the ecological performance indicators is based on eco-efficiency and is equal to the value of products and/or services divided by the impact on environment. On the other hand, the ISO has promulgated the international standards known as the ISO 14000 series on environmental performance evaluation since 1994. In 1999, the International Standards Organisation (ISO) released IS014031 standards titled "Environmental Performance Evaluation Standards" (ISO, 1999), which mainly contained a framework for designing and implementing environmental performance audits in an organisation. The environmental performance indicators promulgated by the ISO consist of management performance indicators (MPIs) and operational performance indicators (OPIs). The UNCTAD has eight areas of environmental performance indicators which include: (1) environmental impact, (2) emissions and waste indicators, (3) input indicators, (4) resource consumption indicators, (5) efficiency indicators, (6) risk indicators of potential environmental impact, (7) customer indicators, and (8) financial indicators. The GRI promulgated sustainability reporting standards and/or guidelines and mainly emphasises corporate responsibility activities on the economic, social and environmental issues.

Trumpp et al. (2015) have done an extensive review of literature on CEP and, rather than undertaking a pointless repetition, this is presented as a summarised literature review in TABLE 1 . Note how, over time, the concept of CEP has been refined and the dimensions thereof condensed within two dimensions. Trumpp et al. indicate that, while the dimensions of EMP and Environmental Operational Performance (EOP) of CEP are mentioned in different ways in the literature, they can satisfactorily be summed up in these two dimensions. For instance, under $E O P$ environmental results and environmental impact are items that refer to the measuring of EOP.

TABLE 1: Summarised Literature Review on Conceptualisation and Dimensions of CEP

\begin{tabular}{|c|c|c|c|}
\hline Author/s & $\begin{array}{c}\text { Environmental } \\
\text { Management } \\
\text { Performance }(\varepsilon M P)\end{array}$ & $\begin{array}{c}\text { Environmental } \\
\text { Operational Performance } \\
(\varepsilon O P)\end{array}$ & Other dimensions \\
\hline $\begin{array}{l}\text { Wells et al. } \\
\text { (1992) }\end{array}$ & - Process improvement & - Environmental results & $\begin{array}{l}\text { - Customer } \\
\text { satisfaction }\end{array}$ \\
\hline
\end{tabular}




\begin{tabular}{|c|c|c|c|}
\hline Author/s & $\begin{array}{c}\text { Environmental } \\
\text { Management } \\
\text { Performance (EMP) }\end{array}$ & $\begin{array}{c}\text { Environmental } \\
\text { Operational Performance } \\
(\varepsilon O P)\end{array}$ & Other dimensions \\
\hline $\begin{array}{l}\text { Azzone et al. } \\
(1996)\end{array}$ & $\begin{array}{l}\text { - Environmental policy } \\
\text { - Environmental } \\
\text { management system } \\
\text { (commitment, } \\
\text { compliance, } \\
\text { stakeholder) }\end{array}$ & $\begin{array}{l}\text { Environmental } \\
\text { performance of } \\
\text { products and services } \\
\text { (eco balance analysis) }\end{array}$ & $\begin{array}{l}\text { - Impact on the state } \\
\text { of the environment }\end{array}$ \\
\hline $\begin{array}{l}\text { llinitch et al. } \\
\text { (1998) }\end{array}$ & - Organisational system & $\begin{array}{l}\text { - Environmental impacts } \\
\text { - Regulatory compliance }\end{array}$ & $\begin{array}{l}\text { - Stakeholder } \\
\text { relations }\end{array}$ \\
\hline $\begin{array}{l}\text { Rikhardsson } \\
\text { (1998) }\end{array}$ & $\begin{array}{l}\text { - Environmental } \\
\text { management system } \\
\text { (policy, objectives) }\end{array}$ & $\begin{array}{l}\text { - Operations } \\
\text { - Environmental impact }\end{array}$ & $\begin{array}{l}\text { - Products life cycle } \\
\text { analysis } \\
\text { - Financial issues }\end{array}$ \\
\hline $\begin{array}{l}\text { Young and } \\
\text { Welford } \\
\text { (1998) }\end{array}$ & $\begin{array}{l}\text { - Environmental policy } \\
\text { - Environmental } \\
\text { management system } \\
\text { - (commitment, } \\
\text { compliance, } \\
\text { stakeholder) }\end{array}$ & $\begin{array}{l}\text { - Environmental } \\
\text { performance of } \\
\text { products } \\
\text { - and services (eco } \\
\text { balance analysis) }\end{array}$ & - \\
\hline $\begin{array}{l}\text { Jung et al. } \\
(2001)\end{array}$ & $\begin{array}{l}\text { - General environmental } \\
\text { management (policy, } \\
\text { objectives, information } \\
\text { system, audit) } \\
\text { - Process/operation }\end{array}$ & $\begin{array}{ll}\text { - } & \text { Input } \\
\text { - } & \text { Output }\end{array}$ & $\begin{array}{l}\text { - Outcome } \\
\text { (financial, non- } \\
\text { financial) }\end{array}$ \\
\hline $\begin{array}{l}\text { Lefebvre et al. } \\
(2003)\end{array}$ & $\begin{array}{l}\text { - Product life cycle } \\
\text { management } \\
\text { - Environmental } \\
\text { management system (in } \\
\text { line with ISO 14001) } \\
\text { - Environmental R\&D } \\
\text { expenditures }\end{array}$ & - & - \\
\hline Rao et al. (2006) & $\begin{array}{l}\text { - Environmental } \\
\text { management }\end{array}$ & $\begin{array}{l}\text { - Environmental } \\
\text { performance } \\
\text { (input, output) }\end{array}$ & \\
\hline $\begin{array}{l}\text { Xie and Hayase } \\
(2007)\end{array}$ & $\begin{array}{l}\text { - Environmental } \\
\text { management } \\
\text { performance } \\
\text { - (organisational system, } \\
\text { operational } \\
\text { - countermeasures, } \\
\text { environmental tracking) }\end{array}$ & $\begin{array}{l}\text { - Environmental } \\
\text { operational } \\
\text { performance } \\
\text { (inputs, outputs) }\end{array}$ & $\begin{array}{l}\text { - Stakeholder } \\
\text { relations }\end{array}$ \\
\hline ISO 14001 & $\begin{array}{l}\text { - Environmental } \\
\text { management } \\
\text { performance }\end{array}$ & $\begin{array}{l}\text { - Environmental } \\
\text { operational } \\
\text { performance }\end{array}$ & $\begin{array}{l}\text { - Environmental } \\
\text { condition }\end{array}$ \\
\hline
\end{tabular}

Source: Adapted from Trumpp et al. (2015) 
Bhattachayyra and Cummings (2015), however, measure CEP from the stakeholder engagement perspective, while Escrig-Olmedo et al. (2015) measure CEP from a sustainable development point of view. Escrig-0lmedo et al. (Ibid.) conceptualise CEP as having four dimensions which combine industry practice, theoretical and academic practice application. The major groups for EMP are then identified as: (1) strategic intent, (2) governance and management and (3) engagement. Under EOP there is the fourth - operational performance. 'Strategic intent' assesses the level of intent of an organisation in addressing environmental issues, 'governance and management' assesses the implementation of CEP strategies, and 'engagement' refers to the level at which stakeholders are engaged in terms of quality of information presented by the organisation on sustainability and the independent monitoring process thereof. Finally, 'operational performance' measures how effective the companies have implemented their environmental strategies, management systems and stakeholder engagement mechanisms.

For their CEP measurement under EMP, Bhattacharyyra and Cummings (2015) on the other hand have four managerial performance indicators, with two operational performance indicators under EOP. With regard to EMP the indicators are organisational system, stakeholder relations, operational counter measures, and environmental tracking. Concerning the $\varepsilon O P$, there are inputs and outputs. Bhattacharyyra and Cummings (2015) and Trumpp et al. (2015) seem to agree with the conceptual EPM model presented in FIGURE 1. However, Bhattacharyyra and Cummings (2015) are specific on the indicators. It can be observed that the CEP model for Trumpp et al. (2015) is a conceptual framework that can be used in measuring (EP in any context, while that by Bhattacharyyra and Cummings (2015) is an example of adaptation. The indicators for the stakeholder view CEP model have been adapted from Xie and Hayase (2007).

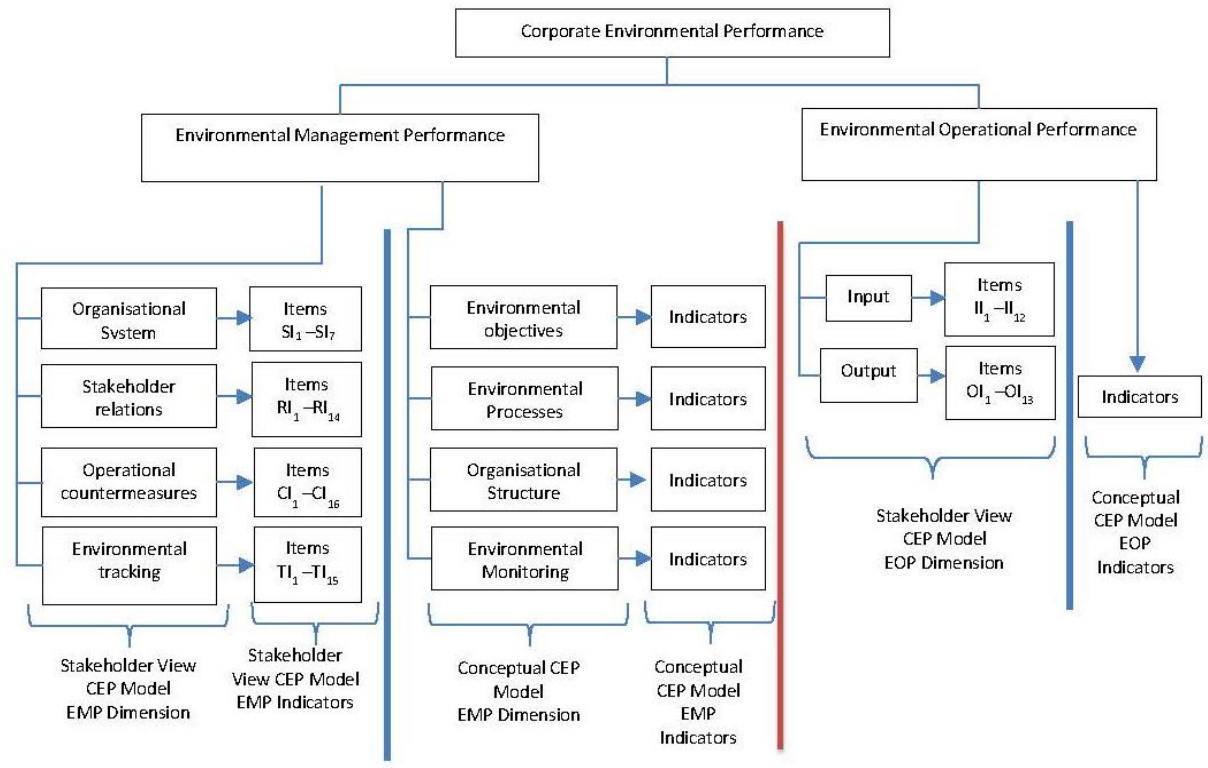

FIGURE 1: $\quad$ The Conceptual EPM Model

Source: $\quad$ Authors, based on Bhattacharyyra and Cummings (2015), Trumpp et al. (2015) 
Following the preceding background information on bank performance and the environmental performance models, it is imperative to review studies that combine these two issues. The next section reviews theoretical and empirical studies that have explored banking environmental performance.

\subsection{Environmental performance in financial institutions}

Allet (2011) conceptualises a framework for measuring environmental performance in microfinance institutions (MFIs) and proposes a new tool called the Microfinance Environmental Performance Index (MEPI), which measures the MEPI along five dimensions: (1) adoption of environmental policy, (2) reducing the internal ecological footprint, (3) managing portfolio environmental risks assessment, (4) providing green microcredit and (5) providing environmental non-financial services. TABLE 2 presents the rubric of the MEPI, albeit very narrowly and mainly focused on the scope of an MFI.

\section{TABLE 2: Microfinance Environmental Performance Index (MEPI) scoring rubric}

\begin{tabular}{|c|c|c|}
\hline 1. ENVIRONMENTAL POLICY & & Score \\
\hline Mission/vision/values & $\begin{array}{l}\text { Environmental protection mentioned in the official vision, } \\
\text { mission, or values }\end{array}$ & 1 \\
\hline Environmental policy & Formal policy on environmental responsibility & 1 \\
\hline Environmental manager & A person appointed to manage environmental issues & 1 \\
\hline Incentives & $\begin{array}{l}\text { Incentive system to encourage employees to take into } \\
\text { account specific environmental objectives }\end{array}$ & 1 \\
\hline \multicolumn{3}{|l|}{ 2. عCOLOGICAL FOOTPRINT } \\
\hline Carbon audit & Previous realization of a carbon audit & 1 \\
\hline Footprint objectives & $\begin{array}{l}\text { Specific objectives to reduce ecological footprint (e.g., } \\
\text { reduction in energy consumption, carbon emissions, waste, } \\
\text { etc.) }\end{array}$ & 1 \\
\hline Staff awareness & $\begin{array}{l}\text { Toolkits to raise employees' awareness of good practices in } \\
\text { paper, water, and energy consumption, transportation, waste } \\
\text { management, etc. }\end{array}$ & 1 \\
\hline Reporting & $\begin{array}{l}\text { Inclusion of environmental performance indicators in annual } \\
\text { report (paper, water, and energy consumption, etc.) }\end{array}$ & 1 \\
\hline \multicolumn{3}{|c|}{ 3. ENVIRONMENTAL RISKS ASSESSMENT } \\
\hline Exclusion list & Use of an environmental exclusion list & 1 \\
\hline Screening tools & $\begin{array}{l}\text { Use of specific toolkits to evaluate the environmental risks of } \\
\text { clients' activities }\end{array}$ & 1 \\
\hline Staff training & $\begin{array}{l}\text { Training module to teach loan officers how to evaluate the } \\
\text { environmental risks of their clients' activities }\end{array}$ & 1 \\
\hline Miscellaneous & $\begin{array}{l}\text { Inclusion of indicators into Monitoring and Information } \\
\text { System (MIS) to track the environmental performance of } \\
\text { clients }\end{array}$ & 1 \\
\hline
\end{tabular}




\begin{tabular}{|c|c|c|}
\hline \multicolumn{3}{|l|}{ 4. GREEN MICROCREDIT } \\
\hline $\begin{array}{l}\text { Renewable energy and } \\
\text { energy efficiency loans }\end{array}$ & $\begin{array}{l}\text { Provision of credits to promote access to renewable energy or } \\
\text { energy efficient technologies (RE\&\&EE) }\end{array}$ & 2 \\
\hline Green IGAs loans & $\begin{array}{l}\text { Provision of loans with reduced interest rates to promote the } \\
\text { development of environmentally-friendly activities }\end{array}$ & 2 \\
\hline \multicolumn{3}{|c|}{ 5. ENVIRONMENTAL NON-FINANCIAL SERVICES } \\
\hline Client Chart & Environmental chart to be signed by clients & 1 \\
\hline Client Awareness & Programs to raise clients' awareness on environmental risks & 1 \\
\hline Promotion Action & $\begin{array}{l}\text { Organisation of actions to promote environmentally-friendly } \\
\text { microenterprises }\end{array}$ & 1 \\
\hline Client Training & $\begin{array}{l}\text { Training and other services to support clients who want to } \\
\text { develop environmentally-friendly activities }\end{array}$ & 1 \\
\hline
\end{tabular}

Source: Allet (2011)

There is a plethora of proposed models for measuring the environmental performance of financial institutions. In this section we only look at those focusing on the financial sector. A study done by Allet and Hudon (2013) on measuring environmental performance in $160 \mathrm{MFIs}$ worldwide provides a broad model that can be applied to financial institutions. The environmental performance measurement used in this study is based on the MEPI model discussed earlier, as recommended by Allet (2014), which Forcella and Hudon (2014) also utilised in their measuring of the environmental performance of European MFIs. Forcella and Hudon indicate that the size of an MFI and investor concern for environmental performance, to a lesser extent, are related to the environmental performance of an MFI. On the other hand, Allet and Hudon indicate that larger MFIs tend to perform better in terms of environmental policy and environmental risk assessment. Moreover, they found that financial performance is not significantly related to environmental performance.

Schmid-Schonbein and Braunschweig (2000) conducted a study in which they formulated the EPIs to be used in measuring environmental performance in the financial industry. Banks were categorised in the same manner as the Global Reporting Initiative's (GRI) G4 Guidelines and the Financial Services Sector Disclosures (FSS, 2013). They proposed an environmental performance model based on $\varepsilon P I s$ within an organisation and environmental condition indicators ( $(\mathrm{Cls}$ ) outside of the institution. The $\varepsilon P I s$ are divided into Management Performance Indicators and Operational Performance Indicators, as discussed earlier. The MPIs are intended for environmental management systems in the financial services sectors, and OPIs are for the actual financial services. However, the study could not cover the $\mathrm{ECls}$, since no studies had been done and no measures were available to ascertain how the changes to the environment outside of the financial institution affect its performance. FIGURE 2 shows the Overall Environmental Performance indicators recommended by Schmid-Schonbein and Braunschweig (2000).

Another alternative measure of environmental performance is the climate-friendly metrics, which are recommended in three categories, namely: (1) carbon metrics (2) green/brown exposure metrics and (3) climate scores (Dupre et al., 2015). Carbon metrics are indicators based on greenhouse gas (GHG) emissions, that is, the carbon footprint of financial institutions' financial services and energy efficiency-related reductions indicators. Green/brown exposure metrics are indicators distinguishing between climate solutions and climate problems at technology, industry or sector level. Climate (ESG - Environmental, Social and Governance) scores are qualitative 
indicators provided by specialised ESG analysts based on quantitative and qualitative climate indicators, including carbon and green/brown exposure metrics.

\begin{tabular}{|c|c|c|c|c|c|}
\hline Indicators & $\begin{array}{l}\text { Commercial } \\
\text { Banking }\end{array}$ & $\begin{array}{l}\text { Investment } \\
\text { Banking }\end{array}$ & $\begin{array}{l}\text { Asset } \\
\text { Management }\end{array}$ & Insurance & $\begin{array}{l}\text { In-house } \\
\text { Ecology }\end{array}$ \\
\hline \multicolumn{6}{|c|}{ Management Performance indicators (MPI): } \\
\hline 1: Know-how & \multicolumn{4}{|c|}{ Environmentally relevant posts and environmental departments } & ditto \\
\hline 2: Training & \multicolumn{4}{|c|}{ Environmental management training } & ditto \\
\hline 3: Auditing & \multicolumn{4}{|c|}{ Environmental management audits } & ditto \\
\hline \multicolumn{6}{|c|}{ Operational Performante indicators (OPI): } \\
\hline $\begin{array}{l}\text { 4: Integration into the } \\
\text { core business }\end{array}$ & $\begin{array}{l}\text { Environmental risk } \\
\text { check }\end{array}$ & $\begin{array}{l}\text { Ervironmental } \\
\text { risk check }\end{array}$ & $\begin{array}{l}\text { "Asset under } \\
\text { Green } \\
\text { Management" }\end{array}$ & $\begin{array}{l}\text { Environmental } \\
\text { risk check }\end{array}$ & \multirow{2}{*}{$\begin{array}{l}7 \text { Vfu Indicators } \\
\text { - Electricity } \\
\text { - Heating } \\
\text { - Water } \\
\text { - Paper } \\
\text { - Waste Disposal } \\
\text { - Transport } \\
\text { - } \mathrm{CO}_{2}\end{array}$} \\
\hline $\begin{array}{l}\text { 5: Environmentally } \\
\text { oriented services }\end{array}$ & $\begin{array}{l}\text { Financing } \\
\text { environmentally } \\
\text { oriented pioneers }\end{array}$ & $\begin{array}{l}\text { Transactions } \\
\text { with } \\
\text { environmentally } \\
\text { oriented } \\
\text { pioneers }\end{array}$ & $\begin{array}{l}\text { Investments in } \\
\text { Environmentally } \\
\text { oriented pioneers } \\
\text { risk check }\end{array}$ & $\begin{array}{l}\text { Environmentally } \\
\text { innovative policies }\end{array}$ & \\
\hline
\end{tabular}

FIGURE 2: $\quad$ Overview of Environmental Performance Indicators for the Financial Industry

Source: Schmid-Schonbein and Braunschweig (2000)

One of the few studies on the environmental performance of banks is that of KPMG (2012), which looked in particular at the ESG performance of Swedish banks and asset management companies with the use of World Wildlife Fund (WWF) topics. Due to the ubiquitous indicators under the WWF topics, this discussion is limited to relevant environmental indicators drawn from topics that include decarbonisation of the economy, water, soft commodities, mining and hydropower. The benchmark framework contained four building blocks: (1) sustainability strategy of the banks, (2) integration of ESG into business activities, (3) product and service offerings and (4) the governance framework. The authors observed that ESG is better integrated in lending than in mainstream asset management activities, but asset management companies performed better in mainstreaming ESG into investments. Another important outcome of the study was the observation that banks seem not to consider environmental issues as strategic and hence apply sector-specific policies or general sustainability policies in dealing with ESG risk, and adhere to minimum standards as far as possible. The main aim was therefore to find the leading practice bank with good practice in the areas of risk management, governance, ESG integration and environmental issues related to water, soft commodities, mining and hydropower.

Most banking institutions use environmental performance indicators recommended by the GRI (2013). The EPIs are part of the recommended sustainability reporting guidelines for the financial services sector. The sustainability reporting guidelines recommend specific standard disclosure from financial institutions with regard to economic, environmental and social issues. As per the GRI G4 FSSS guidelines (GRI G4 FSSS), environmental indicators cover performance regarding material, energy, water and outputs such as emissions, effluents, waste. In addition, they cover performance related to biodiversity, environmental compliance, and other relevant information such as environmental expenditure and the impacts of products and services. This seems to be informed by the Greenhouse Gas Protocol, which forms the basis of a measuring tool - currently 
being drafted - for carbon emissions from financial sector activities. Having set a theoretical foundation for the study, the next section explains the materials and methods applied in carrying out this research.

\section{MATERIALS AND METHODS}

\subsection{Methodological framework}

In order to create the bank environmental performance indicators for measuring EPI, a couple of reviewed frameworks were used. Informed by literature in the field, the CEP of banks can apparently be measured on three fronts, namely (1) environmental management performance (EMP), (2) environmental operational performance (EOP) and (3) environmental conditional indicators ( $E \mathrm{Cl})$ (Trumpp et al., 2015). The researchers mainly adopt the environmental performance indicators, that is, the EMP and EOP indicators, based on the framework by Jasch (2000) and Trumpp et al. (2015). This framework was deemed fit for the study since it is built on the widely recognised IS014031 standard of environmental performance evaluation of 1999, itself based on the material flow balance of the organisation's operational system and listing the indicators for the management system and the impact of the organisation's activities on the environment outside of its operations. The framework by Jasch (Ibid) is also built on the GRI guidelines discussed earlier in the literature review.

Jasch (2000) defines EOP indicators based on the input-output material flow balance, for example materials, energy, water consumption, waste and emissions in total amounts and production volumes. EOP indicators are very important in communicating environmental data to both internal and external stakeholders of an organisation. EMP indicators are described by Jasch (Ibid) as measuring the indirect environmental efforts and results attained by an organisation to influence its environmental objectives. Examples from the host of EMP indicators are the number of environmental audits, staff training, supplier audits, cases of non-compliance in environmental regulations, and environmentally certified sites. The $\varepsilon \mathrm{Cl}$ s are explained as the direct measure of the quality of the environment and these indicators show the impact of emissions or pollutants from a company's production on water and air. Examples of $\varepsilon \mathrm{Cl}$ s are noise from airports, air quality for power stations, and water quality for pulp and paper industries. FIGURE 3 illustrates the bank EPI designed for this research.

After consideration of the methodological framework above, a bank EMP scoring index was formulated to be used for screening and extracting the relevant questions from the CDP questionnaire answers supplied by the banks (only for the EMP). This was done by extracting the relevant questions that relate to FIGURE 3, whose framework is mainly based on the CDP questionnaire and is not exhaustive in that it does not give a complete measure of bank environmental performance. TABLE 3 shows the detailed EMP scoring index that was utilised thereafter. The highest score a bank could attain was 24 and an average of 12 was deemed high performance in managing environmental issues. For the EOP other aspects were left out because of lack of data such as water consumption, financing of renewable energy, and loans that finance environmentally sensitive projects and activities.

The $E O P$ results were tabulated as well and aggregated as per the average of each country. The final analysis was to correlate EMP against EOP to find the kind of correlation that exists between these two variables. The EMP score was correlated with EOP proxy measures of average benchmarking and this was meant to counteract the issues of size, especially when comparing the 
EMP and EOP of the banks per country. By aggregating the results per country it was convenient to see the banks in the light of how, on average, they are using environmental issues as an edge for competition in the respective markets.

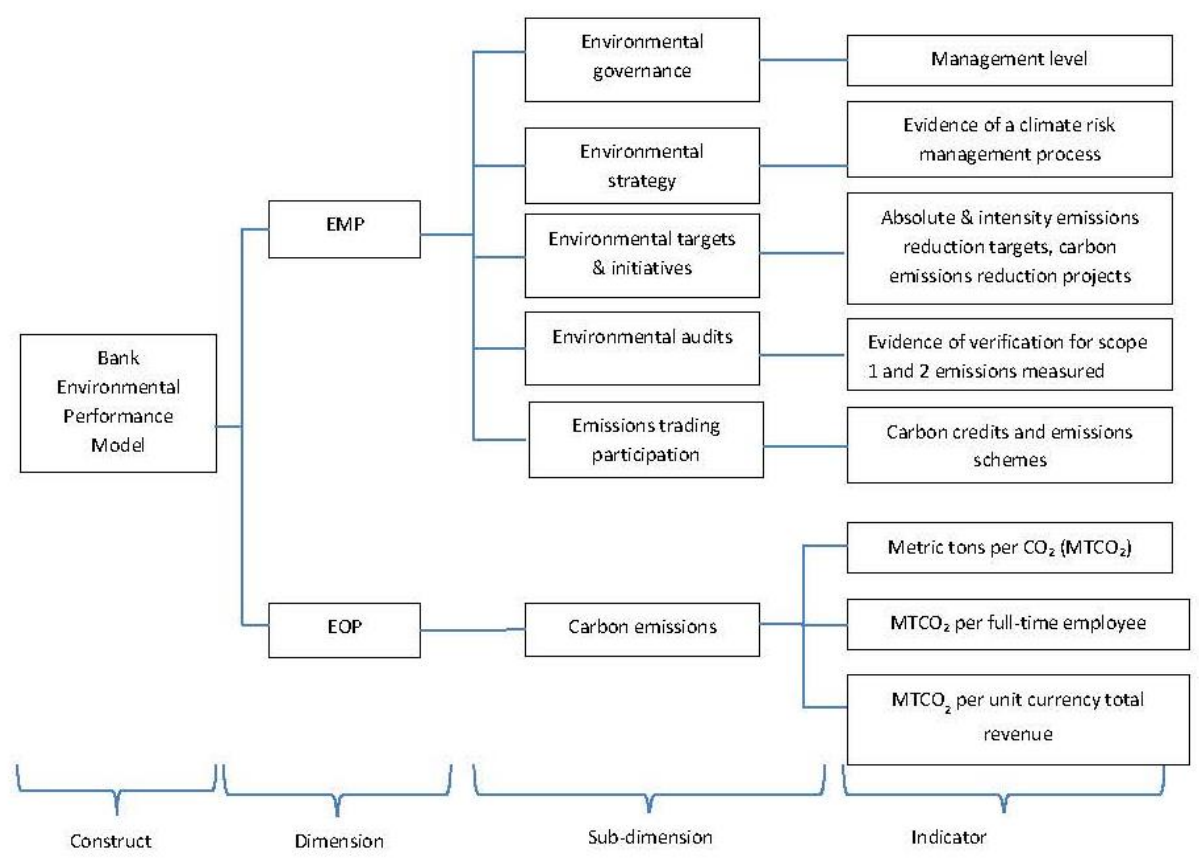

\section{FIGURE 3: $\quad$ Proposed framework of Bank CEP}

Source: $\quad$ Authors'deduction

The analysis would assist to ascertain the relevancy of environmental issues in banking operations at country level. The EOP proxies being used represent the direct emissions (Scope 1) caused by the banks' operations and indirect emissions (Scope 2) caused by the banks utilising external resources such as electricity and fuel to produce their products and services.

\section{TABLE 3: Bank EMP scoring index}

\begin{tabular}{|c|c|c|c|}
\hline $\begin{array}{c}\varepsilon P / \text { sub- } \\
\text { dimension }\end{array}$ & Details of EPI-indicator & $\begin{array}{l}\text { Reference of } \\
\text { EPI from CDP } \\
\text { questionnaires }\end{array}$ & Coding of $E P I$ \\
\hline \multirow[t]{2}{*}{$\begin{array}{l}\text { Environmental } \\
\text { governance/ } \\
\text { organisational } \\
\text { structure }\end{array}$} & $\begin{array}{l}\text { Where is the highest level of direct } \\
\text { responsibility for climate change } \\
\text { within your organisation? }\end{array}$ & $\begin{array}{l}\text { pl.1 ( } 2011 \text { - } \\
2014)\end{array}$ & $\begin{array}{l}\text { Board/Executive }-4 \\
\text { Senior management }-3 \\
\text { Middle management }-2 \\
\text { Junior management - } 1\end{array}$ \\
\hline & $\begin{array}{l}\text { Do you provide incentives for the } \\
\text { management of climate change issues, } \\
\text { including the attainment of targets? }\end{array}$ & $\begin{array}{l}01.2(2011- \\
2014)\end{array}$ & $\begin{array}{l}\text { Yes - } 1 \\
\text { No N/A - } 0\end{array}$ \\
\hline
\end{tabular}




\begin{tabular}{|c|c|c|c|}
\hline $\begin{array}{l}\varepsilon P / \text { sub- } \\
\text { dimension }\end{array}$ & Details of EPI-indicator & $\begin{array}{l}\text { Reference of } \\
\text { EPI from CDP } \\
\text { questionnaires }\end{array}$ & Coding of $E P /$ \\
\hline \multirow[t]{3}{*}{$\begin{array}{l}\text { Environmental } \\
\text { strategy }\end{array}$} & $\begin{array}{l}\text { Please select the option that best } \\
\text { describes your risk management } \\
\text { procedures with regard to climate } \\
\text { change risks and opportunities. }\end{array}$ & $\begin{array}{l}\text { Q2.1(2011- } \\
2014)\end{array}$ & $\begin{array}{l}\text { A specific climate change } \\
\text { risk management process } \\
\text { - } 2 \\
\text { Integrated into multi- } \\
\text { disciplinary companywide } \\
\text { risk management } \\
\text { processes - } 1 \\
\text { There are no documented } \\
\text { processes for assessing } \\
\text { and managing risks and } \\
\text { opportunities from } \\
\text { climate change - } 0\end{array}$ \\
\hline & $\begin{array}{l}\text { Is climate change integrated into your } \\
\text { business strategy? }\end{array}$ & $\begin{array}{l}\text { Q2.2(2011- } \\
2014)\end{array}$ & $\begin{array}{l}\text { Yes }-1 \\
\text { No N/A -0 }\end{array}$ \\
\hline & $\begin{array}{l}\text { Do you engage in activities that could } \\
\text { either directly or indirectly influence } \\
\text { public policy on climate change } \\
\text { through any of the following? (tick all } \\
\text { that apply) }\end{array}$ & $\begin{array}{l}\text { Q2.3 (2011- } \\
2014)\end{array}$ & $\begin{array}{l}\text { direct }-2 \\
\text { Yes/Indirect - } 1 \\
\text { No N/A -0 }\end{array}$ \\
\hline \multirow[t]{4}{*}{$\begin{array}{l}\text { Environmental } \\
\text { targets \& } \\
\text { initiatives }\end{array}$} & $\begin{array}{l}\text { Did you have an emissions reduction } \\
\text { target that was active (on-going or } \\
\text { reached completion) in the reporting } \\
\text { year? }\end{array}$ & $\begin{array}{l}03.1(2011- \\
2014)\end{array}$ & $\begin{array}{l}\text { Absolute } \& \text { intensity } \\
\text { target }-2 \\
\text { Intensity or absolute } \\
\text { target }-1 \\
\text { None }-0\end{array}$ \\
\hline & $\begin{array}{l}\text { Please provide details of your absolute } \\
\text { target. }\end{array}$ & $\begin{array}{l}\text { Q3.1a: }(2011- \\
\text { 2014) }\end{array}$ & $\begin{array}{l}\text { Emissions reduction } \\
\text { target } \\
71>-5 \\
51-70 \%-4 \\
41-50 \%-3 \\
21-40 \%-2 \\
020 \%-1 \\
\text { Not Provided - } 0\end{array}$ \\
\hline & $\begin{array}{l}\text { Did you have emissions reduction } \\
\text { initiatives that were active within the } \\
\text { reporting year? (This can include those } \\
\text { in the planning and implementation } \\
\text { phases.) }\end{array}$ & $\begin{array}{l}\text { Q3.3: (2011- } \\
\text { 2014) }\end{array}$ & $\begin{array}{l}\text { Yes }-1 \\
\text { No N/A - } 0\end{array}$ \\
\hline & $\begin{array}{l}\text { Please identify the total number of } \\
\text { projects at each stage of } \\
\text { development, and for those in the } \\
\text { implementation stages, the estimated } \\
\text { CO2e savings. }\end{array}$ & $\begin{array}{l}\text { Q3.3:a }(2011- \\
\text { 2014) }\end{array}$ & $\begin{array}{l}\text { implemented - } 2 \\
\text { to be implemented or } \\
\text { under investigation - } 1 \\
\text { not to be implemented - } \\
0\end{array}$ \\
\hline $\begin{array}{l}\text { Environmental } \\
\text { audits }\end{array}$ & $\begin{array}{l}\text { Please indicate the } \\
\text { verification/assurance status that } \\
\text { applies to your reported Scope } 1 \\
\text { emissions. }\end{array}$ & $\begin{array}{l}\text { Q8.6\& } Q 8.7(2011 \\
-2014)\end{array}$ & $\begin{array}{l}\text { Verification for both } \\
\text { Scope } 1 \text { and } 2-2 \\
\text { For either } 1-1 \\
\text { None- } 0\end{array}$ \\
\hline
\end{tabular}




\begin{tabular}{|c|c|c|c|}
\hline $\begin{array}{l}\varepsilon P / \text { sub- } \\
\text { dimension }\end{array}$ & Details of EPI-indicator & $\begin{array}{l}\text { Reference of } \\
\text { EPI from CDP } \\
\text { questionnaires }\end{array}$ & Coding of EPI \\
\hline & $\begin{array}{l}\text { Please indicate the } \\
\text { verification/assurance status that } \\
\text { applies to your reported Scope } 2 \\
\text { emissions. }\end{array}$ & & \\
\hline \multirow[t]{2}{*}{$\begin{array}{l}\text { Emissions } \\
\text { trading } \\
\text { participation }\end{array}$} & $\begin{array}{l}\text { Do you participate in any emissions } \\
\text { schemes? }\end{array}$ & $\begin{array}{l}\text { P14.1(2011- } \\
2012) \\
013.1(2013- \\
2014)\end{array}$ & $\begin{array}{l}\text { Yes }-1 \\
\text { No } N / A-0\end{array}$ \\
\hline & $\begin{array}{l}\text { Has your organisation originated any } \\
\text { project-based carbon credits or } \\
\text { purchased any within the reporting } \\
\text { period? }\end{array}$ & $\begin{array}{lll}014.2 & (2011 & - \\
2012) & & \\
013.2 & (2013 & - \\
2014) & & \end{array}$ & $\begin{array}{l}\text { Yes }-1 \\
\text { No N/A }-0\end{array}$ \\
\hline
\end{tabular}

Source: Authors' interpretation

\subsection{Data and sample}

The research embarked on collecting data from the banks that participate in the annual CDP reporting, a report which has multi-industrial sector companies participating voluntarily and is widely recognised as a mechanism of carbon and environmental data disclosure in the business world (Kolk, Levy \& Pinkse, 2008; Andrew and Coertese, 2012). This was chosen because the questionnaire used to collect the information provides all the answers that are required for the scoring needed in the CEP indicators. The period for this study is between 2011 and 2014 and the sample of banks is reflected in TABLE 4. The period between 2011 and 2014 was deemed suitable, as most banks included in the sample consistently reported.

TABLE 4: Number of banks in the population and sample by country

\begin{tabular}{lcccccccc}
\hline \multicolumn{1}{c}{ Country } & \multicolumn{3}{c}{ Population } & \multicolumn{5}{c}{ Sample } \\
& 2011 & 2012 & 2013 & 2014 & 2011 & 2012 & 2013 & 2014 \\
\hline Argentina & 1 & 1 & 1 & 1 & 1 & 1 & 1 & 1 \\
Australia & 5 & 5 & 6 & 6 & 4 & 4 & 4 & 4 \\
Austria & 2 & 2 & 2 & 2 & 2 & 2 & 2 & 2 \\
Belgium & 1 & 1 & 1 & 1 & & & & \\
Brazil & 4 & 5 & 4 & 6 & 4 & 4 & 4 & 4 \\
Canada & 7 & 6 & 7 & 6 & 4 & 4 & 4 & 4 \\
China & 2 & 1 & 1 & 1 & & & & \\
Colombia & 0 & & 0 & 1 & & & & \\
Denmark & 1 & 1 & 1 & 1 & & & & 4 \\
France & 4 & 4 & 4 & 4 & 4 & 4 & 4 & 1 \\
\hline Germany & 3 & 4 & 4 & 3 & 1 & 1 & 1 & 1 \\
\hline Greece & 1 & 2 & 1 & 2 & 1 & 1 & 1 & 1 \\
\hline
\end{tabular}




\begin{tabular}{|c|c|c|c|c|c|c|c|c|}
\hline \multirow{2}{*}{ Country } & \multicolumn{4}{|c|}{ Population } & \multicolumn{4}{|c|}{ Sample } \\
\hline & 2011 & 2012 & 2013 & 2014 & 2011 & 2012 & 2013 & 2014 \\
\hline Hong Kong & 1 & 1 & 1 & 1 & 1 & 1 & 1 & 1 \\
\hline India & 5 & 5 & 5 & 5 & 3 & 3 & 3 & 3 \\
\hline Ireland & 0 & 0 & 1 & 1 & & & & \\
\hline Israel & 1 & 0 & 0 & 0 & & & & \\
\hline Italy & 5 & 4 & 6 & 7 & 3 & 3 & 3 & 3 \\
\hline Japan & 7 & 5 & 4 & 10 & 2 & 2 & 2 & 2 \\
\hline Liechtenstein & 1 & 1 & 1 & 2 & 1 & 1 & 1 & 1 \\
\hline Malaysia & 0 & 0 & 1 & 0 & & & & \\
\hline Mexico & 2 & 2 & 2 & 1 & 1 & 1 & 1 & 1 \\
\hline Netherlands & 0 & 0 & 0 & 1 & & & & \\
\hline Norway & 1 & 1 & 1 & 1 & 1 & 1 & 1 & 1 \\
\hline Peru & 1 & 1 & 1 & 1 & 1 & 1 & 1 & 1 \\
\hline Philippines & 1 & 0 & 0 & 0 & & & & \\
\hline Poland & 1 & 1 & 1 & 1 & 1 & 1 & 1 & 1 \\
\hline Portugal & 4 & 4 & 4 & 4 & 3 & 3 & 3 & 3 \\
\hline Russia & 0 & 0 & 0 & 1 & & & & \\
\hline Singapore & 0 & 1 & 1 & 1 & & & & \\
\hline South Africa & 5 & 3 & 3 & 3 & 3 & 3 & 3 & 3 \\
\hline South Korea & 7 & 8 & 8 & 9 & 3 & 3 & 3 & 3 \\
\hline Spain & 6 & 6 & 6 & 7 & 5 & 5 & 5 & 5 \\
\hline Sweden & 4 & 3 & 4 & 4 & 2 & 2 & 2 & 2 \\
\hline Switzerland & 10 & 10 & 9 & 6 & 4 & 4 & 4 & 4 \\
\hline Taiwan & 0 & 1 & 2 & 2 & & & & \\
\hline Thailand & 0 & 0 & 1 & 2 & & & & \\
\hline Turkey & 3 & 2 & 5 & 5 & 2 & 2 & 2 & 2 \\
\hline United Kingdom & 5 & 5 & 6 & 6 & 5 & 5 & 5 & 5 \\
\hline USA & 12 & 13 & 12 & 9 & 6 & 6 & 6 & 6 \\
\hline Grand Total & 113 & 109 & 117 & 124 & 68 & 68 & 68 & 68 \\
\hline
\end{tabular}

Source: Authors' analysis

The sampling was done by determining the banks per country which consistently participated in the CDP from 2011 to 2014. European countries have the highest number of participating banks in the CDP with the exception of the Netherlands, Belgium and Denmark. However, the USA has the highest number of consistently reporting banks in the sample of six in the period under study. This was followed by Spain with five. Out of 39 countries that participate in the CDP programme, only 26 have more than one bank that consistently participates; the final sample had 68 banks. The samples for EMP and EOP are different, with EMP having 26 countries while the EOP has 22 countries. Hong Kong, Peru, Poland and Liechtenstein had banks which were consistent in reporting EMP indicators, but inconsistent in reporting EOP indicators and they were dropped for 
the EOP analysis. After sampling, the researchers analysed the data and the findings on the EMP and $\varepsilon O P$ are presented and discussed in the next section.

\section{RESULTS AND DISCUSSION}

From the analysis the outcomes are presented in TABLES 5, 6, 7 and 8. In TABLE 5, the EMP scores are aggregated per country in average terms. Banks in a country that attained more than the sample total average EMP score for the particular year were deemed high performers. For instance, the average score in 2011 is 11.69 and countries with EMP scores above this average sample score are deemed high performers, with those below this score are deemed low performers. Germany has the banks with the highest overall EMP score from 2011 to 2014, followed by banks in Australia. South Africa is the only African country in the sample from Africa and ranks third in EMP scores. The five low performers are Greece, Japan, India, Peru and Liechtenstein, scoring the lowest EMP score. Interestingly, Canada and USA are below the period average score and rank 15 and 19 respectively out of the 26 countries in the sample.

TABLE 5: Average EMP score per country

\begin{tabular}{lccccc}
\hline \multirow{1}{*}{ Country } & \multicolumn{5}{c}{ Average of EMP Score for: } \\
\hline Germany & 2011 & 2012 & 2013 & 2014 & $(2011-2014)$ \\
\hline Australia & 14 & 16 & 20 & 20 & 17.5 \\
\hline South Africa & 16 & 16.5 & 17.75 & 18 & 17.06 \\
\hline United Kingdom & 13 & 15.33 & 17.33 & 18 & 15.92 \\
\hline Sweden & 14.4 & 15.4 & 16.8 & 16.8 & 15.85 \\
\hline South Korea & 15.5 & 13 & 13 & 17 & 14.63 \\
\hline Norway & 13 & 14.33 & 15.33 & 15 & 14.42 \\
\hline Austria & 9 & 13 & 16 & 18 & 14.00 \\
\hline Italy & 9 & 10.5 & 18.5 & 17.5 & 13.88 \\
\hline Brazil & 11.67 & 16 & 12 & 15.67 & 13.83 \\
\hline France & 12.25 & 13 & 13.75 & 15.5 & 13.63 \\
\hline Switzerland & 13.25 & 12.25 & 13.25 & 15.25 & 13.50 \\
\hline Spain & 12.5 & 13.5 & 15.5 & 11.5 & 13.25 \\
\hline Sample Average & 12.8 & 13.2 & 11.6 & 15.2 & 13.20 \\
\hline Turkey & 11.69 & 12.5 & 13.54 & 14.4 & 13.03 \\
\hline Canada & 11 & 11 & 12.5 & 17.5 & 13.00 \\
\hline Portugal & 11.75 & 12.5 & 13.25 & 13.25 & 12.69 \\
\hline Hong Kong & 11.33 & 12 & 12 & 12.67 & 12.00 \\
\hline Mexico & 12 & 12 & 11 & 11 & 11.50 \\
\hline USA & 8 & 10 & 13 & 14 & 11.25 \\
\hline Argentina & 9.17 & 10.67 & 12.33 & 12.33 & 11.13 \\
\hline & 9 & 9 & 12 & 11 & 10.25 \\
\hline
\end{tabular}




\begin{tabular}{lccccc}
\hline \multirow{2}{*}{ Country } & \multicolumn{5}{c}{ Average of EMP Score for: } \\
& 2011 & 2012 & 2013 & 2014 & $(2011-2014)$ \\
\hline Poland & 9 & 10 & 11 & 10 & 10.00 \\
Greece & 9 & 9 & 10 & 10 & 9.50 \\
Japan & 8 & 8.5 & 11 & 10.5 & 9.50 \\
India & 8.33 & 7.67 & 7.67 & 11 & 8.67 \\
Peru & 9 & 10 & 7 & 6 & 8.00 \\
Liechtenstein & 3 & 1 & 8 & 9 & 5.25 \\
\hline
\end{tabular}

Source: Authors' analysis

It should be noted that countries that proactively support international climate change policies have banks that score high in EMP scores. Most European countries, including the United Kingdom, Germany and France, are in the forefront of championing international environmental policies. The USA is an example of a country which was not willing to rectify some of the internationally recognised climate change policies such as the Kyoto protocol, possibly explaining the country's low EMP score. Hong Kong is a proxy for China's overall EMP scores and is just below the sample average in the EMP scores. China is of interest since it is a huge global manufacturing hub and the decisions that banks take reflect how banks can impact the environmental performance of their financial services. Note too that nine out of the thirteen countries that are above the sample average are European countries. This shows how international environmental policies and country environmental legislation are being adopted and incorporated in the environmental frameworks of banks in the European region.

In TABLE 6 the average carbon emissions per country are presented. Average carbon emissions have been ranked by the average metric tonnes of carbon emissions measured between 2011 and 2014 for banks in each country. It can be observed that most countries with high EMP scores have higher carbon emissions, which is an indication of how these banks are appropriately incorporating environmental management policies and are properly measuring the carbon emissions produced by their operations. This means the low-scoring countries have weak environmental management frameworks that do not assist proper measurement of carbon emissions, or management of the impact of environmental risks on the operations of these banks. Banks in seven out of the 26 countries in the sample are responsible for emissions higher than the average for the sample. There are four highly industrialised and developed countries, namely the USA, United Kingdom, Germany and France in the top seven and only two developing countries, namely India and South Africa, which are emerging markets with growing industrialisation. On average the Scope 2 emissions were increasing from 2011, reached their apex in 2013, and in 2014 recorded a decrease. However, Scope 1 emissions increased in 2011, decreased in 2012, and then experienced a continuous increase in the years 2013 and 2014.

With reference to the EOP results (TABLE 7), India had outlier data which pushed the sample average higher, rendering most of the banks in the sample below average. Most of the banks in the countries that scored high in EMP lie close to the average of the sample. However, the results are not consistent with EMP scores. A high EMP score should bring a lower EOP result, which indicates that the environment management system being implemented by a bank results in a reduced $\varepsilon O P$. 


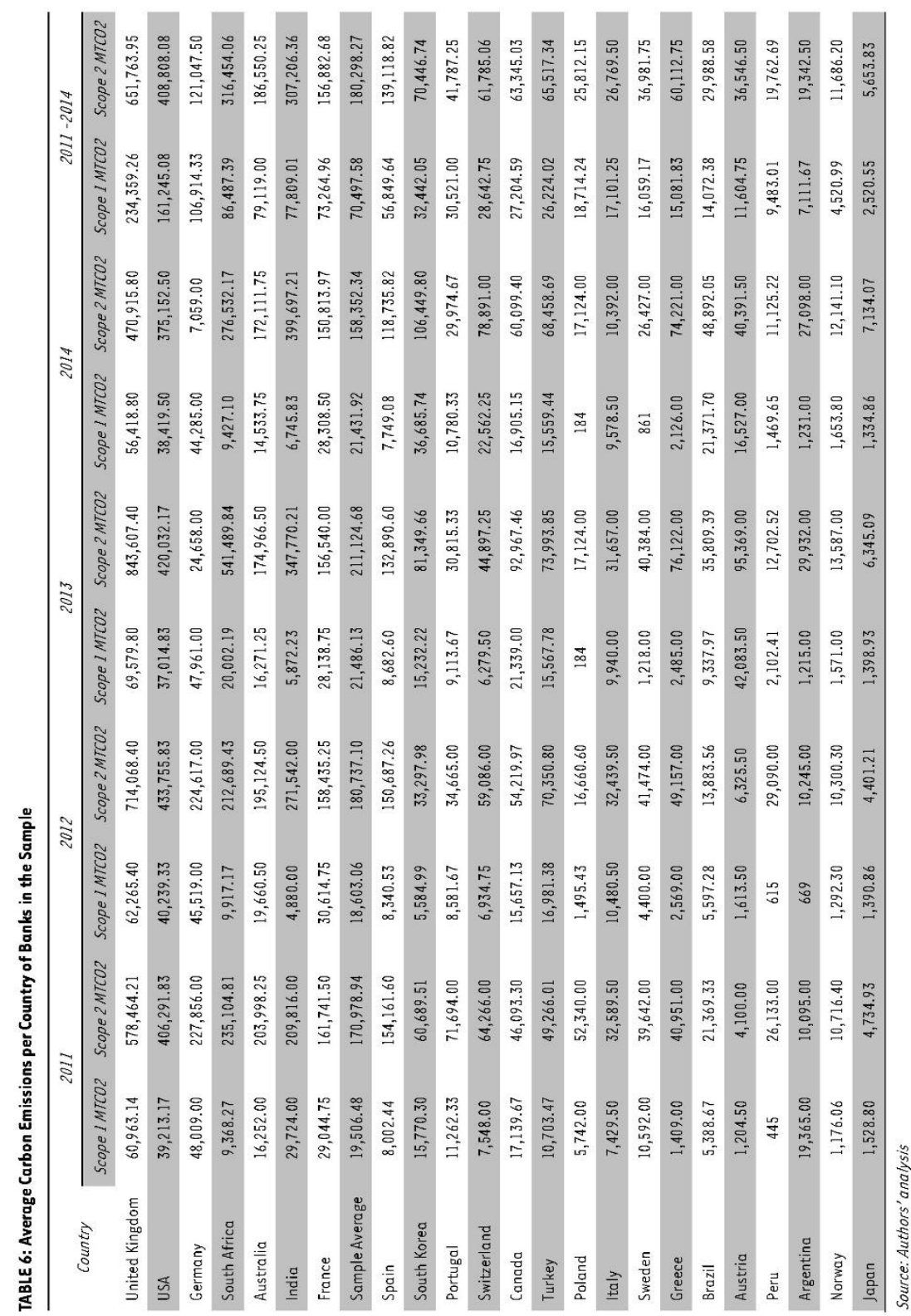




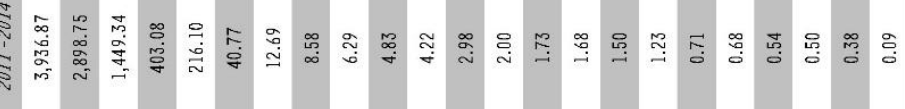

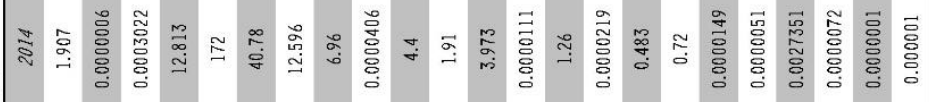

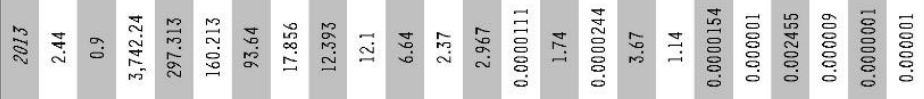

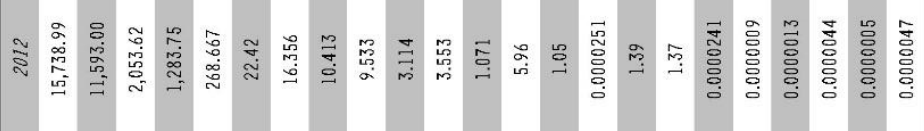

究

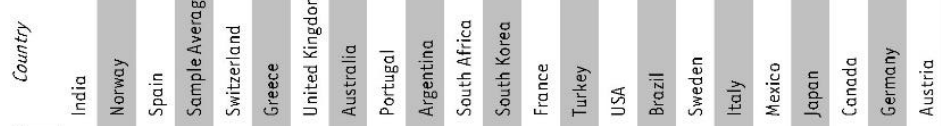

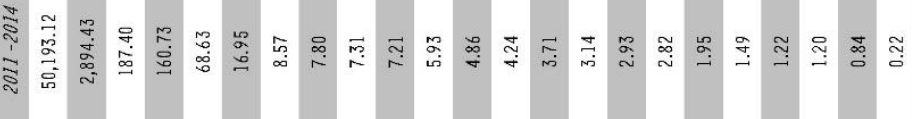

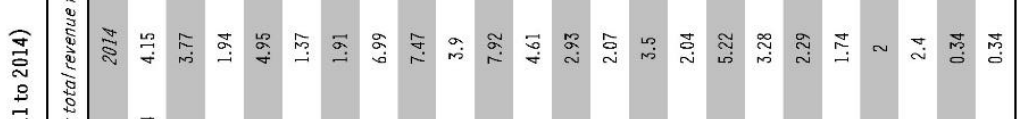

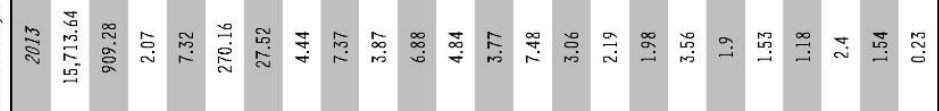

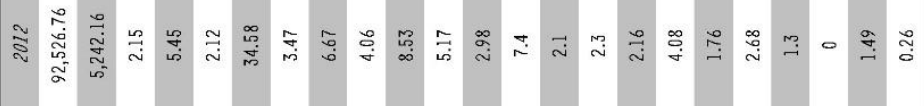

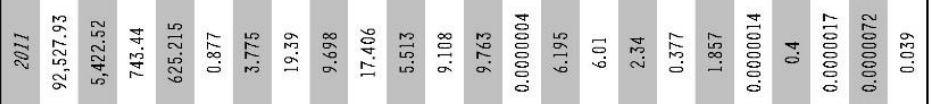

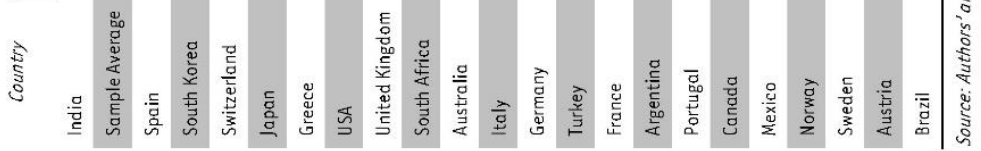


For instance, some banks in Germany had the highest EMP average score for the combined period 2011 to 2014, yet have lower EOP even though the country does not have the lowest EOP scores. The average total carbon emissions per unit currency total revenue represents the amount of carbon emissions emitted to produce a unit of total revenue. The same explanation is applicable to the average metric tonnes of carbon per full time employment. There are therefore inconsistencies in the relationship between a country's EMP average score when it is directly compared to their EOP results. For example, Japan had an EMP average score that was below the sample average, yet it has a poor metric tonne of carbon dioxide (MTC02) measure per unit currency of total revenue and a better measure for the same per full time employee. On the other hand, countries like Spain, Switzerland and the United Kingdom have a high EMP score but have both poor metric tonnes of carbon dioxide per unit currency of total revenue, and metric tonnes of carbon per fulltime employee results, compared to other countries. Such mixed results led to a further analysis of the data to find the correlation between EMP score and the two EOP proxies.

Generally the results of the Pearson correlation analysis show a significant negative correlation between EMP scores and the EOP proxies. The EMP Scores (TABLE 8) correlated to metric tonnes of carbon dioxide per unit currency of total revenue (Pearson Correlation 1) and the EMP scores correlated to metric tonnes of carbon dioxide per fulltime employee (Pearson Correlation 2). Most countries show a significant strong negative correlation in both Pearson correlation 1 and 2 analyses, and only Argentina had a significant positive correlation in both of these correlation analyses. India (which had a low EMP average score) had insignificant weak correlation with both EOP proxies. This means that a weak environmental management policy is not an important factor in having EOP results that are high for banks in India. For countries that have an average EMP score that is above sample average, only Spain, Norway and South Korea had an insignificant correlation between EMP average score and MTCO2 per unit currency of total revenue.

TABLE 8: Pearson correlation results of EMP and عOP

\begin{tabular}{|c|c|c|}
\hline Country & Pearson Correlation 1 & Pearson Correlation 2 \\
\hline Argentina & $0.957 * \star \star *$ & $0.965 * \star \star *$ \\
\hline Australia & $-0.074 * \star \star *$ & $-0.955 * \star \star *$ \\
\hline Austria & 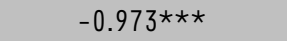 & 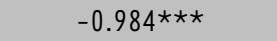 \\
\hline Brazil & $0.065 * \star \star$ & 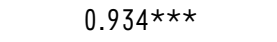 \\
\hline Canada & $-0.870 * \star \star *$ & $0.819 * * *$ \\
\hline France & 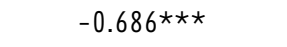 & 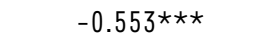 \\
\hline Germany & 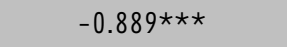 & 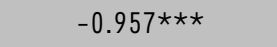 \\
\hline Greece & 0.778 & $0.949 \star \star \star$ \\
\hline India & -0.223 & -0.223 \\
\hline Italy & 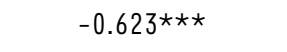 & $0.507 \star \star \star$ \\
\hline Japan & $-0.679 \star \star \star$ & -0.991 \\
\hline Mexico & $0.608 * \star \star$ & $-0.024 * \star \star \star$ \\
\hline Norway & -0.170 & 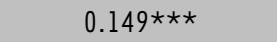 \\
\hline
\end{tabular}




\begin{tabular}{|c|c|c|}
\hline Country & Pearson Correlation I & Pearson Correlation 2 \\
\hline Portugal & -0.025 & $-0.668 * \star \star *$ \\
\hline South Africa & $-0.996 * \star \star *$ & $0.183 * \star \star$ \\
\hline South Korea & -0.914 & 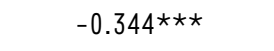 \\
\hline Spain & -0.853 & $-0.741 * \star \star$ \\
\hline Sweden & $-0.665 * \star \star$ & 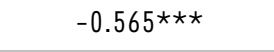 \\
\hline Switzerland & $0.222^{\star \star}$ & -0.500 \\
\hline Turkey & $-0.430 \star \star \star *$ & $0.165^{\star \star \star \star}$ \\
\hline United Kingdom & -0.437 & 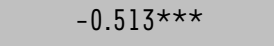 \\
\hline USA & $-0.857 \star \star$ & 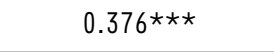 \\
\hline Sample Average & -0.875 & -0.843 \\
\hline
\end{tabular}

Source: Authors' analysis

$\star \star \star x<.05 ; \star \star p<.10$

\section{CONCLUSION}

The analysis conclusively finds that there is a significant negative correlation between EMP and EOP in banking institutions. Banks do not really exert a material impact on the environment through their internal operations, and the implementation of an environmental policy internally cannot conclusively explain whether banks can help alleviate environmental issues. This result can be explained by the use of Scope 1 and 2 emissions in the analysis that are tied to the banks' internal operations. On the other hand, Scope 3 measures the emissions caused in other institutions through the banks' products and services. Therefore Scope 3 emissions are relevant to expand the analysis of how the banks' environmental policies have an impact on operations that are outside their areas of activity. Banks that score high in environmental management performance are located in countries that are proactive in global environment regulation and include most of Western Europe, namely Germany, the United Kingdom, Sweden, Italy, Austria, Norway and France. However, at the same time the high EMP scores do not translate into improved EOP results: for example, countries like Mexico, Brazil and Turkey seem to have improved EOP results while having EMP scores that are below the sample average. Overall, the sample average EMP score has an insignificant negative correlation with the EOP proxies. The implication of this result is that the banks' internal operations do not pose any significant impact on the environment. In addition, banks in countries where there is a huge drive to adopt best standards of environmental management seem to score high in EMP and have properly measured carbon emissions. Banks in countries where environmental management is not fostered seem to have low average EMP scores.

Certain limitations of the research affected the results. First, the timeframe is deemed short, even though it shows some relationship between a given environmental management policy and the output indicators of implementing them. More studies should be done to investigate the longterm relationship between EMP and EOP. Second, many banks in some of the countries participating in the Carbon Disclosure Project (CDP) are not consistent in reporting their 
emissions and environmental initiatives, which leads to unequal participants per geographic region being chosen for the sample. For example, the African region has only one country, South Africa, while Asia is represented by two countries (Japan and South Korea) and Europe boasts an impressive twelve countries. Third, the data is CDP-based, and while it is comprehensive, the voluntary nature of the exercise allows banks to leave out essential data from the CDP questionnaire: for example, participants in the CDP survey can request that their emissions not be made public (as opted for by most banks in China). Finally, banks started submitting their Scope 3 emissions only in 2013 and therefore no meaningful analysis could be done on time series with other variables being used in this study.

Future research should include long (five-year-plus) analyses of the impact of banking operations. This would help to determine the impact of implementing environmental policies in the short term, as well as over longer periods. The scope of $\varepsilon O P$ indicators should be broadened to make the research as robust as possible. In this study we only managed to use the common EOP indicators shared by the banks in the sample. Some EOP indicators that can be used include the metric tonnes of carbon dioxide per currency unit of operational costs. Considerable research is being done to measure the impact of banks' products and services, especially loans. The Greenhouse Protocol is pioneering a study to measure the impact of loans granted on projects funded by them. The ensuing frameworks would be adopted by leading banks in measuring the impact of the lending business - information that would be useful in future research.

There are a number of implications that can be derived from this research. First, the impact on the internal operations of banks cannot be a high priority for policymakers. Research shows that there is a significant negative correlation between implementation of an environmental policy and the outcomes in a bank setup in the short term. Policymakers should therefore expect positive results in the long term for the environmental policies implemented by banks. Second, there is a need to increase the collection of data from banks' products and services and the carbon emissions they cause. It would appear that the more banks make credit available in the market, the more there is a propensity to utilise it for projects that increase carbon emissions (this assertion requires further investigation). Last, banking institutions have no standards against which to measure carbon emissions, both internally and externally. This possibly stems from the fact that banks do not see themselves as a serious threat to the environment, which causes a half-hearted implementation of their environmental policies. For this reason, we call on the banking industry to adopt compulsory environmental standards, in order to increase transparency and to ease compilation of the environmental operational indicators.

\section{LIST OF REFERENCES}

Allen, F. \& Santomero, A.M. (1997). The theory of financial intermediation. Journal of Banking \& Finance, 21(11), pp. 1461-1485.

Allet, M. (2011). Measuring the environmental performance of microfinance: A new tool. Cost Management, 26(2), pp. 6-17.

Allet, M, \& Hudon, M. (2013). Green microfinance: Characteristics of microfinance institutions involved in environmental management. Journal of Business Ethics, 126(3), pp. 395-414.

Andrew, J. \& Cortese, C.L. (2012). Carbon disclosures: Comparability, the carbon disclosure project and the greenhouse gas protocol. Australasian Accounting, Business and Finance Journal, 5(4), pp. 5 18. 
Bhattacharyya, A. \& Cummings, L. (2015). Measuring Corporate Environmental Performance? Stakeholder Engagement Evaluation. Business Strategy and the Environment, 24(5), pp. 309-325.

Diamond, D.W. (1996). Financial intermediation as delegated monitoring: A simple example. FRB Richmond Economic Quarterly, 82(3), pp. 51-66.

Ditz, D.W. \& Ranganathan, J. (1997). Measuring up: Toward a common framework for tracking corporate environmental performance. Washington D.C.: World Resources Institute.

Escrig-OImedo, E., Muñoz-Torres, M.J., Fernández-Izquierdo, M.Á. \& Rivera-Lirio, J.M. (2015). Measuring Corporate Environmental Performance: A Methodology for Sustainable Development. Business Strategy and the Environment, Available at: http://onlinelibrary.wiley.com/doi/10.1002/bse.1904/pdf (accessed 22 March 2015).

GRI (Global Reporting Initiative) FSSS. (2013). G4 Financial Services Sector Disclosures. Amsterdam: Global Reporting Initiative/UNEP Finance Initiative.

IPCC (Intergovernmental Panel on Climate Change). (2014). Climate Change 2014: Synthesis Report. Contribution of Working Groups I, II and III to the Fifth Assessment Report of the Intergovernmental Panel on Climate Change. Geneva: IPCC.

ISO (International Standards Organisation). (1999). IS014031: Environmental Performance Evaluation Standards, 1999. Geneva: ISO.

Jasch, C. (2000). Environmental performance evaluation and indicators. Journal of Cleaner Production, 8(1), pp. 79-88.

Kolk, A., Levy, D. \& Pinkse, J. (2008). Corporate responses in an emerging climate regime: the institutionalization and commensuration of carbon disclosure. European Accounting Review, 17(4), pp. 719-745.

KPMG, (2012). Environmental performance of Swiss banks: Shifting gears towards next generations banking. Geneva: KPMG.

Lewis, A. \& Juravle, C. (2010). Morals, markets and sustainable investments: A qualitative study of 'champions'. Journal of Business Ethics, 93(3), pp. 483-494.

Schmid-Schonbein, 0. \& Braunschweig, A. (2000). Environmental performance indicators for the financial industry. Available at: www.epifinance.com/www.epifinance.com/images/EPI\% (Accessed 16 May 2016).

Trumpp, C., Endrikat, J., Zopf, C. \& Guenther, \&.(2015). Definition, conceptualization, and measurement of corporate environmental performance: A critical examination of a multidimensional construct. Journal of Business Ethics, 126(2), pp. 185-204.

Wan, J. \& Tang, Y. (2014). Literature Review pof Corporate Environmental Performance Evaluation. International Journal of Business and Social Science, 5(5), pp. 29-34.

Warmerdam, W., Christopoulou, A., Herder, A., Bosma, C., Wilde, J.D., Riemersa, M. \& Gelder, J.W.V. (2015). Undermining Our Future - A Study of banks' investments in Selected Companies attributable to Fossil Fuels and Renewable Energy: A Fair Finance Guide International Case Study. Geneva: Profundo BankTrack.

Xie, S. \& Hayase, K. (2007). Corporate environmental performance evaluation: a measurement model and a new concept. Business Strategy and the Environment, 16(2), pp. 148-168. 